\title{
Comparison of spraying nozzles operational parameters of different design
}

\author{
Michat SIEGMUND ${ }^{1}$, Dominik BAEAGA ${ }^{2}$, Dagmar JANÁČOVÁ ${ }^{3 *}$ and Marek KALITA ${ }^{4}$
}

Authors' affiliations and addresses: ${ }^{1}$ KOMAG Institute of Mining Technology, Pszczyńska 37, 44-101 Gliwice, Poland e-mail: msiegmund@komag.eu

${ }^{2}$ KOMAG Institute of Mining Technology, Pszczyńska 37, 44-101 Gliwice, Poland e-mail: dbalaga@komag.eu

${ }^{3}$ Tomas Bata University in Zlin, Faculty of Applied Informatics, Nam. T.G.Masaryka 5555, 76001 Zlin, Czech Republic e-mail: janacova@utb.cz

${ }^{4}$ KOMAG Institute of Mining Technology, Pszczyńska 37, 44-101 Gliwice, Poland e-mail: mkalita@komag.eu

*Correspondence:

Dagmar Janáčová, Tomas Bata University in Zlin, Faculty of Applied Informatics, Nam. T.G.Masaryka 5555, 76001 Zlin, Czech Republic

e-mail: janacova@utb.cz

\section{Funding information:}

European Regional Development Fund under the project CEBIA-Tech No.

CZ.1.05/2.1.00/03.0089

\section{Acknowledgment:}

This work was supported by the European Regional Development Fund under the project CEBIA-Tech No. CZ.1.05/2.1.00/03.0089

\section{How to cite this article:}

Siegmund, M., Bałaga, D., Janáčová, D. and Kalita, M. (2020). Comparison of spraying nozzles operational parameters of different design. Acta Montanistica Slovaca, Volume 25 (1), 24-34

DOI:

https://doi.org/10.46544/AMS.v25i1.3

\begin{abstract}
A general methodology for assessing the spraying nozzles in the aspect of dust control efficiency is presented. The testing process, as well as test results analysis, is described on the example of two designs of spraying nozzles (the author solution and the commercial one). Both nozzle designs are discussed with regard to their structure and principle of operation. Parameters describing the absorption surface area in relation to time and working media flowrate are used for analyses of test results.
\end{abstract}

\section{Keywords}

dust, spraying system, optimization, coal

(C) 2020 by the authors. Submitted for possible open access publication under the terms and conditions of the Creative Commons Attribution (CC BY) license (http://creativecommons.org/licenses/by/4.0/). 


\section{Introduction}

Many design solutions of spraying nozzles for dust control, especially in underground hard coal mines (Prostański \& Vargová, 2018; Bałaga, 2019; Prostański, 2017a; Bałaga, Kalita, Siegmund \& Klimek, 2019; Prostański, 2018) were developed and successfully implemented as well as tools for modelling the dust propagation in mine workings (Prostański, 2015; Prostański, 2017b) were designed in the KOMAG Institute. KOMAG's knowledge is used for the development of new solutions of air-water spraying nozzles. When using the compressed air, the water stream can be atomized to droplets of diameter equal to a dozen or so micrometres. In KOMAG Institute, the STK air-water spraying nozzle with an internal mixing of both agents was developed and implemented (Prostański, 2017a; Prostański, 2013; Prostański, 2012). Spraying systems developed in KOMAG are equipped both with author's designs of spraying nozzles as well as with the nozzles available on the market. Their operational parameters are tested in the KOMAG's laboratory to select their proper type and nozzle diameter. To increase the effectiveness of bonding the dust particles with water droplets, the surface area of dust absorption, i.e. the total surface area of all water drops, should be maximally increased without changing the total volume of the water stream.

Analysis of droplets fraction distribution in a spraying water stream should be used for selection of a proper spraying stream type for the dust control system. Droplets in the atomized water stream make a typical heterogeneous (polydisperse) system, which is characterized by high scatter of drops diameter. Due to the big differentiation in drops sizes of the water stream, the stream is described by the mean drop diameters (Semião, Andrade, Graça Carvalho, 1996). Mean diameter is a representative value, which characterizes a set of the same droplets representing the real drops population. Mean diameter can be different, depending on the parameter of droplets set used for the calculation such as drops number, their diameters, surface areas. It is the parameter used to assess the quality of water dispersion (Chaussonnet, Braun, Dauch, Keller, Sänger, Jakobs, Koch, Kolb, \& Bauer, 2019.; Wang, Tan, Zhang, Li \& Liu, 2019).

Due to the planned application of the developed nozzle design, i.e. to airborne dust control, volumetric Sauter mean diameter D32 was used in part concerning the test results analyses. This diameter is a diameter of a homogenous representative set of the volume of the same drops and the same total surface area as in the real drops set (Orzechowski \& Prywer, 1991; Bałaga, Kalita \& Siegmund, 2019; Chidambaram, Arunachalam \& Vijayaraghavan, 2015).

The generated absorption surface area can be determined for a time unit or for flow intensity of the spraying medium. In (Bałaga, Kalita \& Siegmund, 2019) the authors suggested using the parameter describing the spraying stream in the form of the following absorption surface area of the generated droplets:

- $\mathrm{PA} / \mathrm{T}$ - Absorption surface area of all droplets in a spraying stream produced within time $\mathrm{T}$ equal to 1 $\min$.

- $\mathrm{PA} / \mathrm{W}$ - Absorption surface area of all droplets in a spraying stream produced after dispersing $1 \mathrm{dm}^{3}$ of water.

- $\mathrm{PA} / \mathrm{P}$ - Absorption surface area of all droplets in a spraying stream produced using compressed air of volume equal to $1 \mathrm{Nm}^{3}$.

\section{Testing the operational parameters of the spraying nozzles}

In the KOMAG Institute of Mining Technology, both author's spraying nozzle design and that one available on the market were used in the spraying installations. These spraying nozzles, before their installation in the industrial objects, were tested in the KOMAG laboratory regarding their fractional distribution of droplets and spraying media consumption versus their supply pressure. Comparative tests of the following two designs of spraying nozzles:

the air-water spraying nozzle of flat stream manufactured by BETE, type PF250 (Fig. 1).

author's design solution of STK spraying nozzle, producing the flat stream (Fig. 2),

will be presented.

Two designs of nozzle generating a flat water stream enabling comparison of nozzle operational parameters were used. Tests of water stream parameters for the commercial PF250 spraying nozzle generating a flat stream were conducted within the realization of the doctoral thesis (Bałaga, 2015). Testing the STK type nozzles was realized within the statutory KOMAG's project entitled: Young scientist - Virtual prototyping of spraying nozzles using the additive manufacture technology" (Siegmund, 2016). 

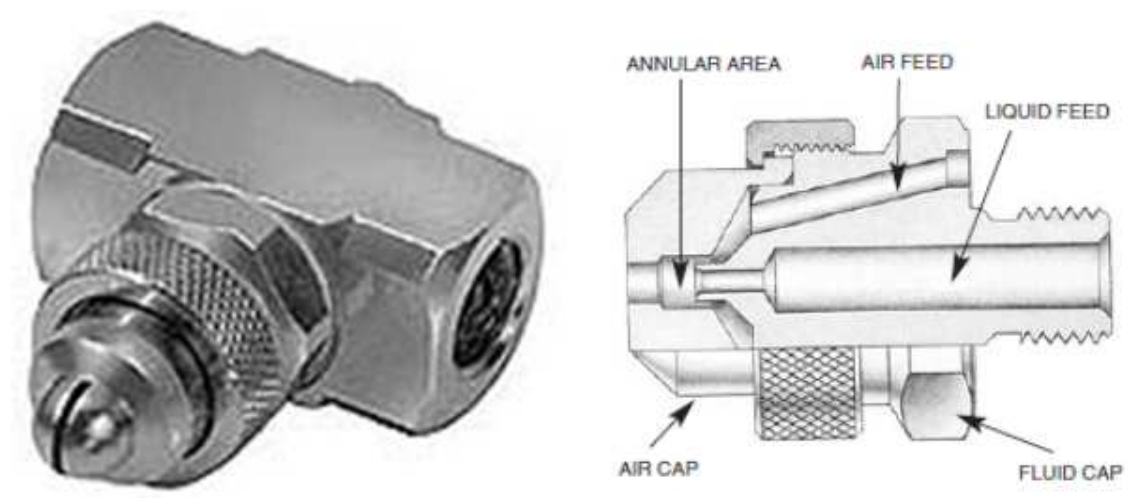

Fig. 1. Design of PF250 nozzle, made by BETE [BETE catalogue]
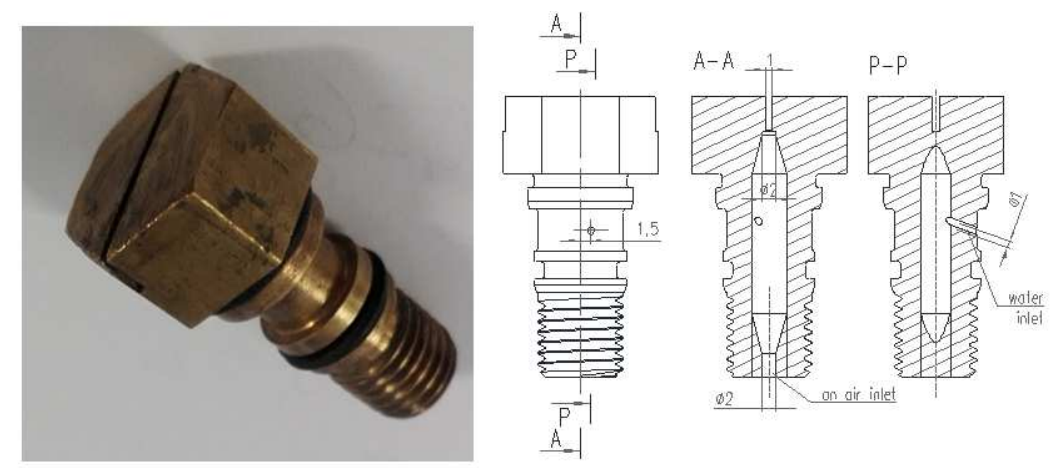

Fig. 2. Design of STK nozzle [Siegmund, 2016]

Testing the nozzles operational parameters consisted of measurements of water flow rate as well as the fractional distribution of droplets in a spraying stream in each nozzle depending on water and compressed air pressures.

Schematic diagram of the test stand is shown in Fig. 3.

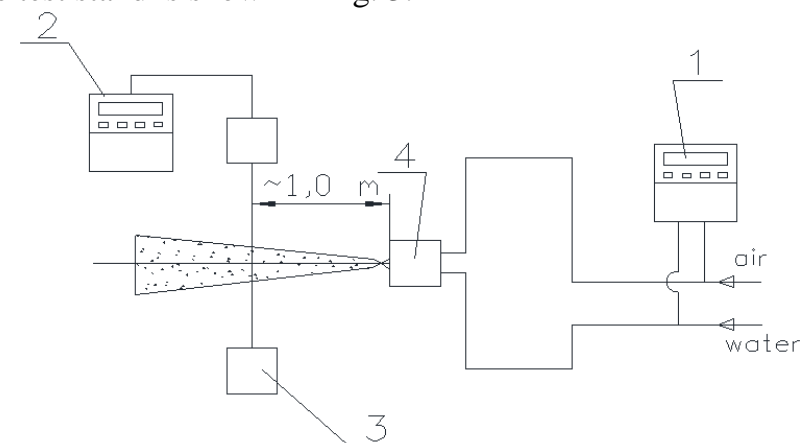

Fig. 3. Schematic diagram of the test stand (Bałaga, 2015; Bałaga \& Jaszczuk, 2016): 1- media measuring unit (water and air), 2 - drops analyzer recording device, 3 - drops analyzer, 4 - air-water nozzle with a fixing body.

During the tests, the following parameters were recorded using the special testing infrastructure (Fig . 4):

- distribution of particles diameter in a sprayed stream of liquid,

- $\quad$ supplying pressure and volumetric airflow rate in air mains supplying the nozzle,

- $\quad$ supplying pressure and volumetric water flowrate in water mains supplying the nozzle.

Tests of drops fractional distribution in a spraying stream generated by PF250 nozzle were conducted for 25 combinations of water and air pressures, which were changed every $0.1 \mathrm{MPa}$ within a range from 0.3 to $0.7 \mathrm{MPa}$. The sample stream generated by PF250 nozzle during the test is given in Fig. 4. 


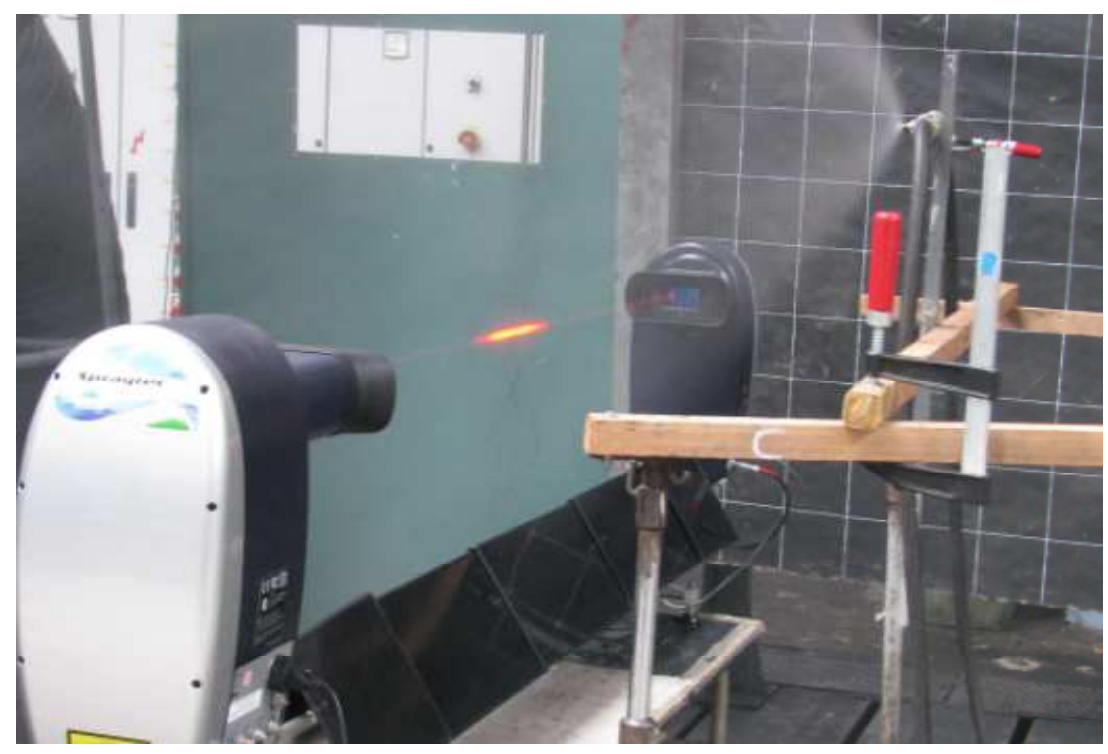

Fig. 4. The test stand during measurements of the distribution of drops diameters in a stream generated by PF250 nozzle (Bałaga, 2015)

For the STK nozzle designed by authors, the measurements were taken for the same pressure of water and air, i.e. $0.3 ; 0.4 ; 0.5$ or $0.6 \mathrm{MPa}$. The same pressures of supply water and air were required by the nozzle design to secure proper operation of the nozzle. The sample stream generated by PF250 nozzle during the test is given in Fig. 5.
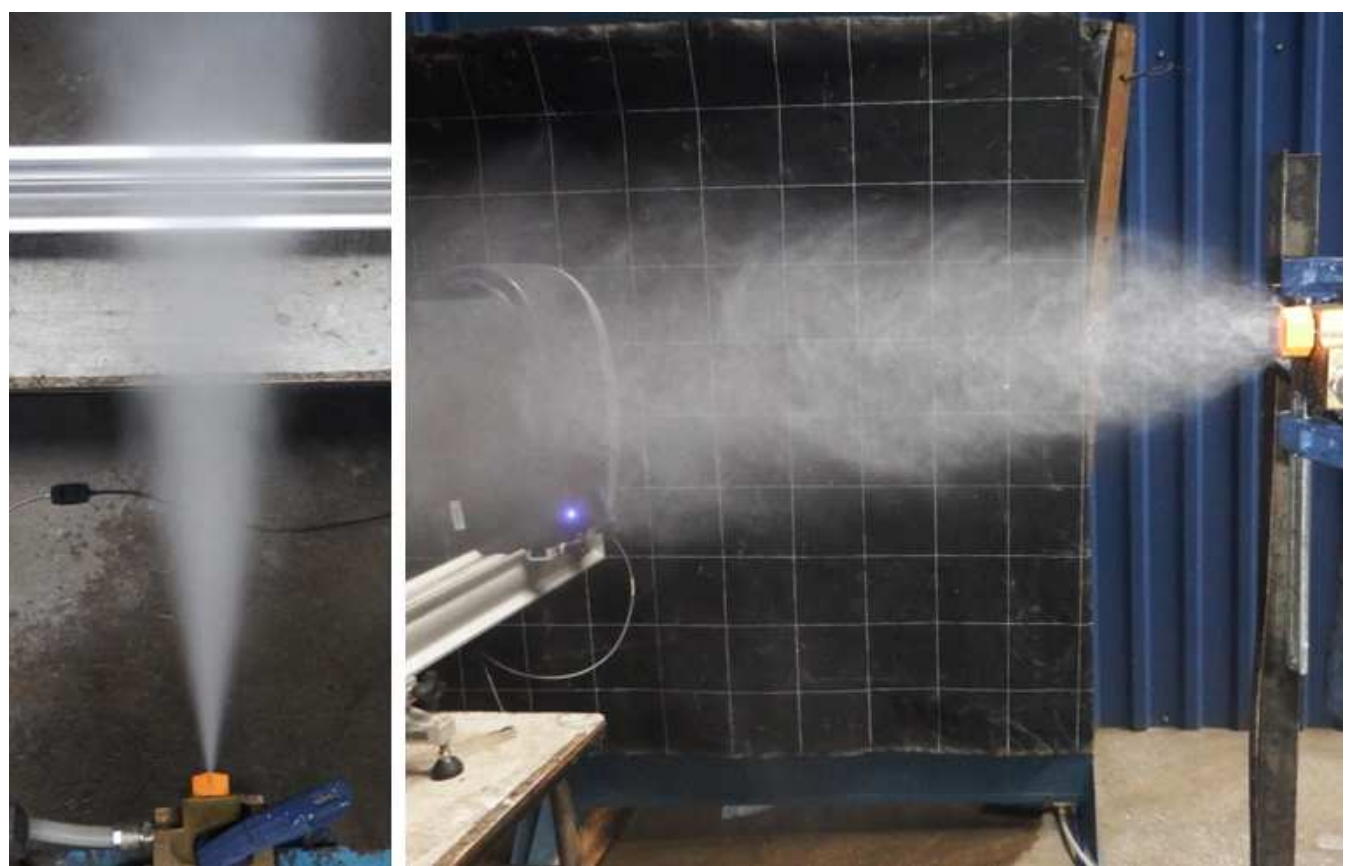

Fig. 5. Flat stream generated by the tested STK nozzle (Siegmund, 2016)

\section{Test results}

The results from testing the parameters of the spraying stream for each combination of water and compressed air pressures for the commercial solution of PF250 nozzle are presented in Table 1. Due to the sensitivity of the measuring device, some of the air flowrate results are not given. On the basis of the measured water and compressed air flow rate, as well as D32 Sauter, mean diameter, absorption surface area of the generated water streams was calculated. Due to lack of complete values of compressed air flowrates for PF250 nozzle, it is not possible to create the diagram of air output and absorption surface area in relation to this output $(\mathrm{PA} / \mathrm{T})$. 
Tab. 1. Results from testing the water stream for different combinations of water and compressed air supply pressures for PF250 nozzle (Bałaga, 2015)

\begin{tabular}{|c|c|c|c|c|c|c|}
\hline $\begin{array}{c}\text { Water supply } \\
\text { pressure } \\
\text { [MPa] }\end{array}$ & $\begin{array}{c}\text { Air supply } \\
\text { pressure } \\
{[M P a]}\end{array}$ & $\begin{array}{c}\text { Water } \\
\text { flowrate } \\
{\left[\mathrm{dm}^{3} / \mathrm{min}\right]}\end{array}$ & $\begin{array}{c}\text { Air flow rate } \\
{\left[\mathrm{Nm}^{3} / \mathrm{min}\right]}\end{array}$ & $\begin{array}{c}\text { Mean } \\
\text { diameter } \\
D(32) \\
{[\mu \mathrm{m}]}\end{array}$ & $\begin{array}{c}\text { Absorption } \\
\text { surface area } \\
P A / T \\
{\left[\mathrm{~m}^{2}\right]}\end{array}$ & $\begin{array}{c}\text { Absorption } \\
\text { surface area } \\
P A / W \\
{\left[m^{2}\right]}\end{array}$ \\
\hline \multirow{5}{*}{0.3} & 0.3 & 1.5 & lack & 109.2 & 82.4 & 54.9 \\
\hline & 0.4 & 1.2 & 0.242 & 63.49 & 113.4 & 94.5 \\
\hline & 0.5 & 1.3 & 0.239 & 29.32 & 266.0 & 204.6 \\
\hline & 0.6 & 0.9 & 0.305 & 24.78 & 217.9 & 242.1 \\
\hline & 0.7 & 0.6 & 0.337 & 19.14 & 188.1 & 313.5 \\
\hline \multirow{5}{*}{0.4} & 0.3 & 1.7 & lack & 134.1 & 76.1 & 44.7 \\
\hline & 0.4 & 1.5 & lack & 99.9 & 90.1 & 60.1 \\
\hline & 0.5 & 1.7 & 0.264 & 56.81 & 179.5 & 105.6 \\
\hline & 0.6 & 1.3 & 0.267 & 44.19 & 176.5 & 135.8 \\
\hline & 0.7 & 1.2 & 0.313 & 26.43 & 272.4 & 227.0 \\
\hline \multirow{5}{*}{0.5} & 0.3 & 2.1 & lack & 138.9 & 90.7 & 43.2 \\
\hline & 0.4 & 2.0 & lack & 118.6 & 101.2 & 50.6 \\
\hline & 0.5 & 2.0 & 0.264 & 82.39 & 145.6 & 72.8 \\
\hline & 0.6 & 1.6 & 0.301 & 60.48 & 158.7 & 99.2 \\
\hline & 0.7 & 1.5 & 0.331 & 37.87 & 237.7 & 158.4 \\
\hline \multirow{5}{*}{0.6} & 0.3 & 2.2 & lack & 129 & 102.3 & 46.5 \\
\hline & 0.4 & 2.1 & lack & 113.6 & 110.9 & 52.8 \\
\hline & 0.5 & 2.0 & lack & 97.88 & 122.6 & 61.3 \\
\hline & 0.6 & 1.8 & 0.252 & 79.75 & 135.4 & 75.2 \\
\hline & 0.7 & 1.5 & 0.301 & 48.5 & 185.6 & 123.7 \\
\hline \multirow{5}{*}{0.7} & 0.3 & 2.2 & lack & 126.9 & 104.0 & 47.3 \\
\hline & 0.4 & 2.2 & lack & 117.8 & 112.1 & 50.9 \\
\hline & 0.5 & 2.1 & 0.238 & 106.3 & 118.5 & 56.4 \\
\hline & 0.6 & 2.0 & 0.301 & 93.43 & 128.4 & 64.2 \\
\hline & 0.7 & 1.8 & 0.324 & 75.41 & 143.2 & 79.6 \\
\hline
\end{tabular}

The results from testing the parameters of the spraying stream for different water and compressed air pressures for STK nozzle are presented in Table 2.

Tab. 2. Results from testing the parameters of spraying stream for different water and compressed air pressures for STK nozzle

\begin{tabular}{|c|c|c|c|c|c|c|c|}
\hline \multicolumn{8}{|c|}{ (Siegmund, 2016) } \\
\hline $\begin{array}{c}\text { Water supply } \\
\text { pressure } \\
{[\mathrm{MPa}]}\end{array}$ & $\begin{array}{c}\text { Air supply } \\
\text { pressure } \\
{[\mathrm{MPa}]}\end{array}$ & $\begin{array}{c}\text { Water } \\
\text { flowrate } \\
{\left[\mathrm{dm}^{3} / \mathrm{min}\right]}\end{array}$ & $\begin{array}{l}\text { Air flow rate } \\
{[\mathrm{Nm} 3 / \mathrm{min}]}\end{array}$ & $\begin{array}{c}\text { Mean } \\
\text { diameter } \\
\mathrm{D}(32) \\
{[\mu \mathrm{m}]} \\
\end{array}$ & $\begin{array}{c}\text { Absorption } \\
\text { surface area } \\
\text { PA/T } \\
{\left[\mathrm{m}^{2}\right]} \\
\end{array}$ & $\begin{array}{c}\text { Absorption } \\
\text { surface area } \\
\text { PA/W } \\
{\left[\mathrm{m}^{2}\right]} \\
\end{array}$ & $\begin{array}{c}\text { Absorption } \\
\text { surface area } \\
\mathrm{PA} / \mathrm{P} \\
{\left[\mathrm{m}^{2}\right]} \\
\end{array}$ \\
\hline 0.3 & 0.3 & 0.20 & 0.06 & 25.5 & 44.7 & 139.5 & 1063.1 \\
\hline 0.4 & 0.4 & 0.14 & 0.101 & 23.4 & 35.7 & 87.0 & 575.0 \\
\hline 0.5 & 0.5 & 0.16 & 0.107 & 19.3 & 73.2 & 146.3 & 101.6 \\
\hline 0.6 & 0.6 & 0.36 & 0.12 & 32.5 & 63.5 & 99.2 & 783.6 \\
\hline
\end{tabular}

On the basis of data from Tables 1 and 2, the comparative diagrams for all the tested combinations of the nozzles supply pressures are created. They are presented in Fig. 6 to 14.

In Fig. 6, diagram of water flowrate changes versus pressures of media supplying the PF250 nozzle is given. Water flowrate is equiproportional to its supply pressure and inverse proportional to the compressed air supply pressure. 


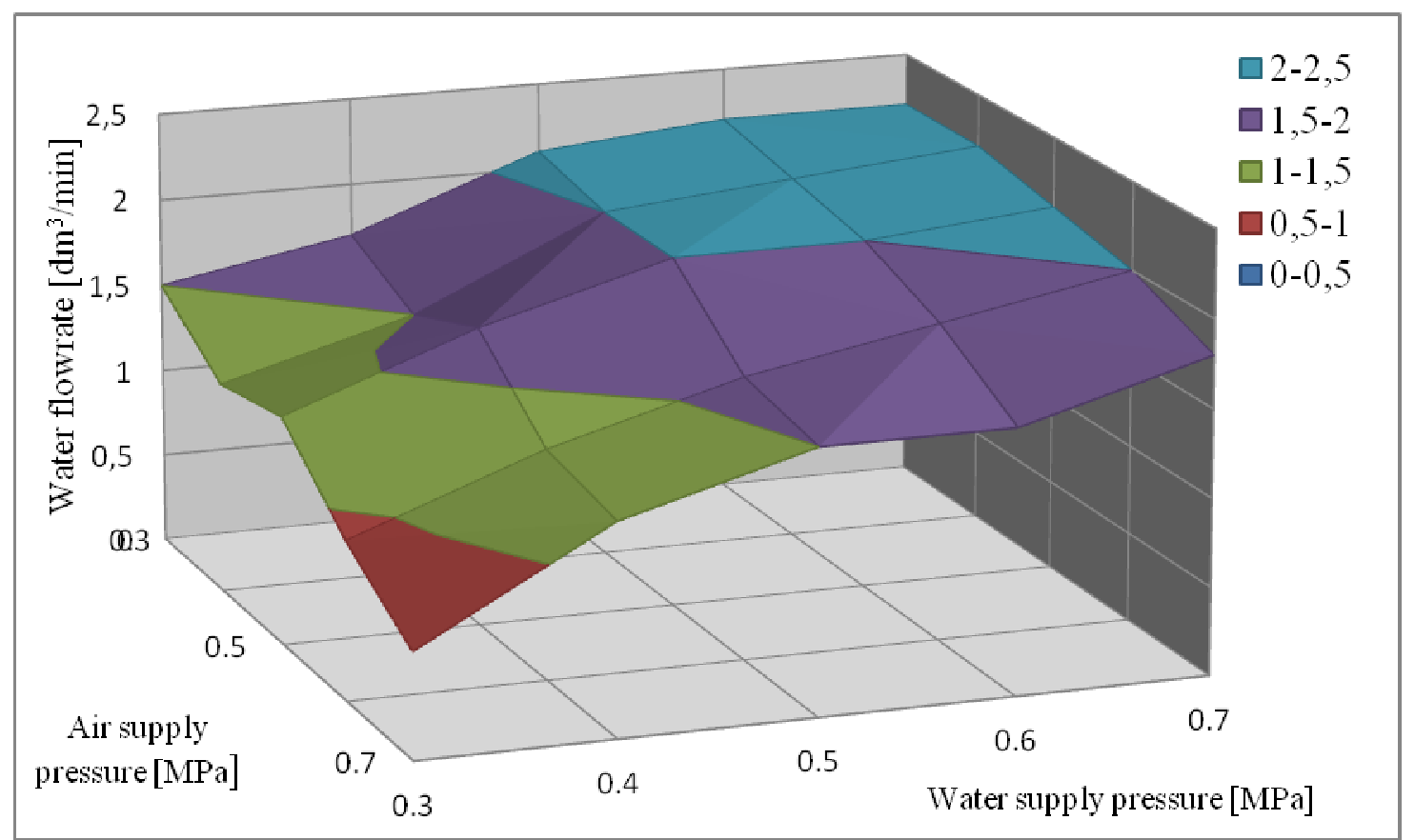

Fig. 6. Water flowrate versus pressures of supplying media in PF250 nozzle

Water flowrate in the case of STK nozzle was significantly lower, and it is given in Fig. 7, where a diagram of water flowrate for PF250 nozzle, when the supply pressure of both media is the same is also given. STK nozzle consumed significantly less water for generation of spraying stream (by about 5 times) than PF250 nozzle.

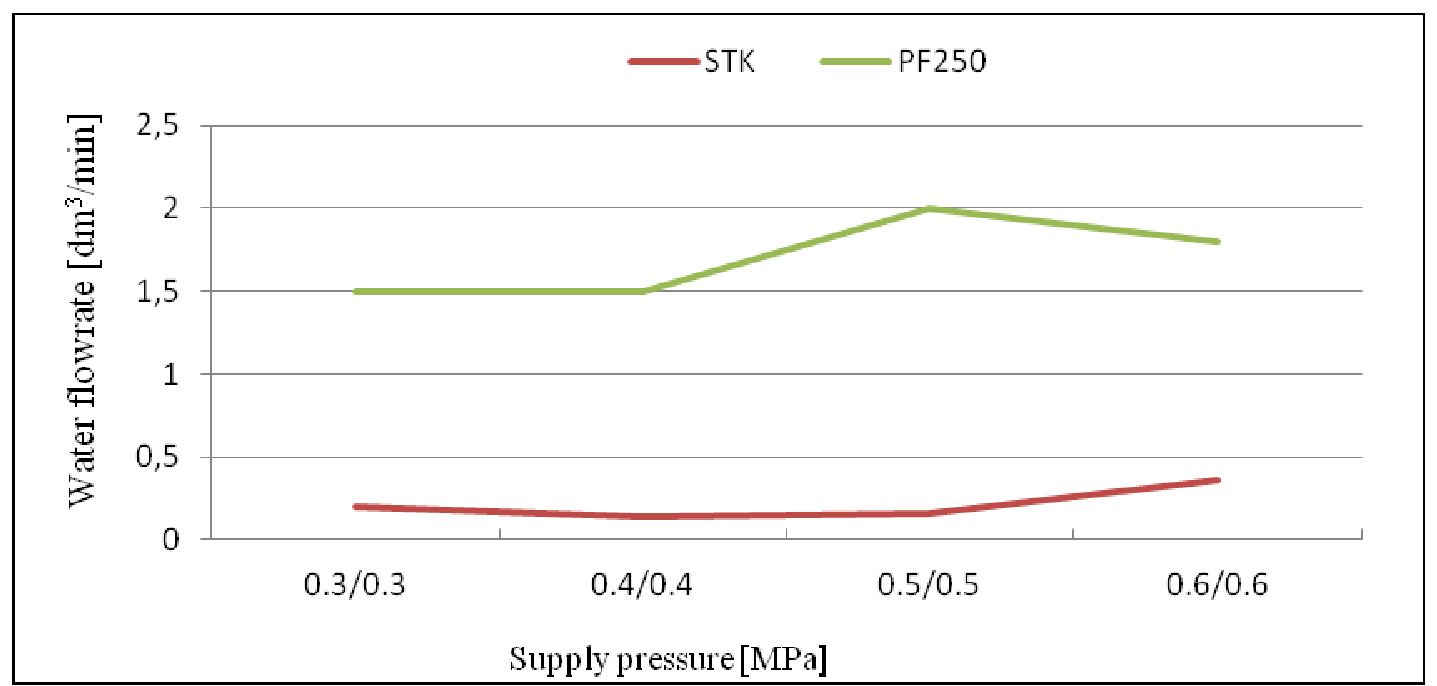

Fig. 7. Comparison of water flowrate versus the supplying media pressure

In Fig. 8, diagram of changes in $\mathrm{D}(32)$ Sauter mean diameter, which is the main parameter of the spraying nozzle, versus pressure of media supplying the PF250, is shown. $D(32)$ mean diameter is smallest for the extremely low water pressure and maximum compressed air pressure. In the case of compressed air pressure drop to a minimum, $\mathrm{D}(32)$ mean diameter is about 3 times bigger. 


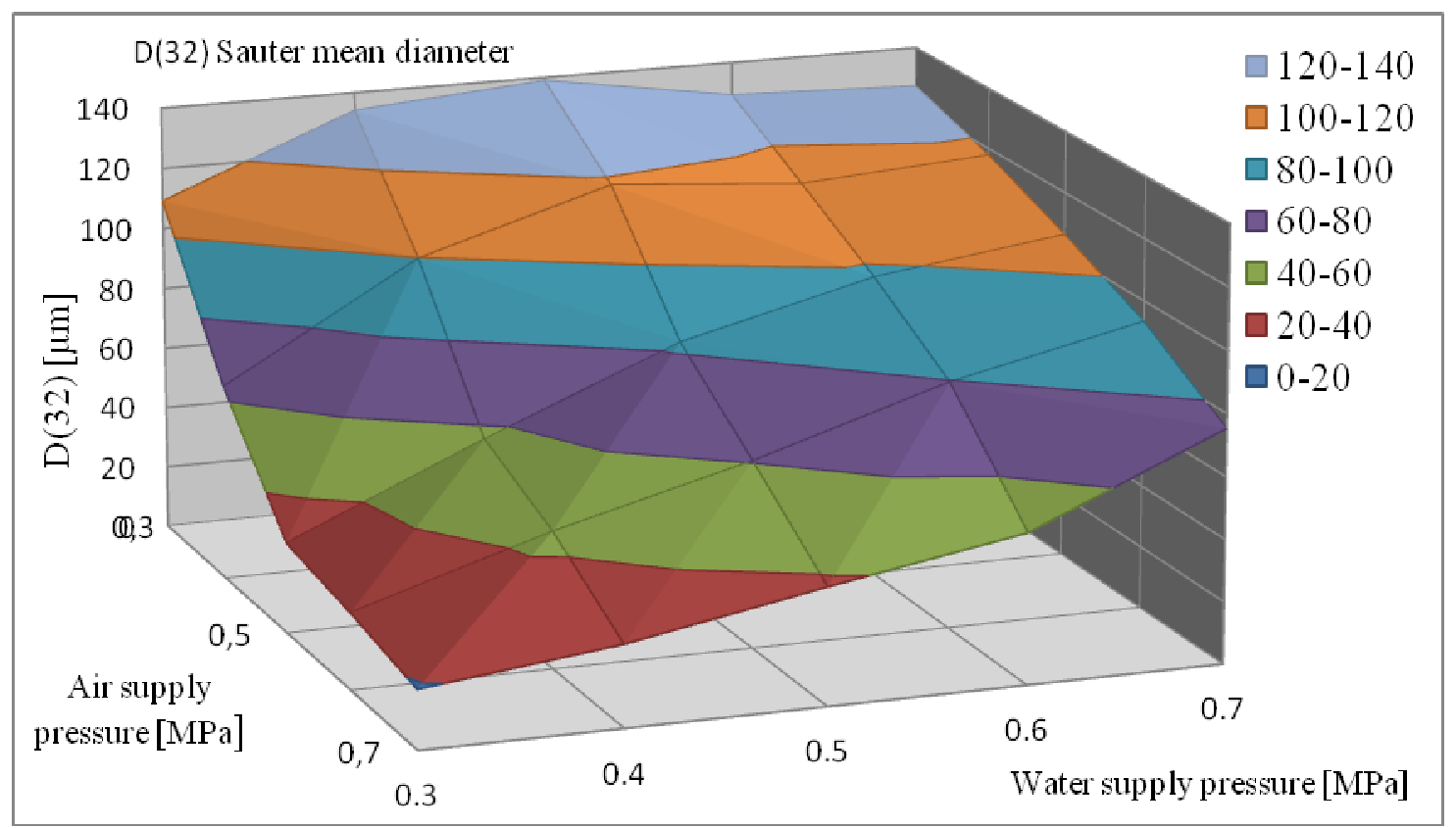

Fig. 8. D(32) mean diameter versus the supplying media pressure for PF250 nozzle

Comparison of $\mathrm{D}(32)$ Sauter mean diameter for both nozzles at the same supply pressure of both media is given in Fig. 9. Significantly bigger (by about 3 times) mean diameter in the case of PF250 nozzle can be observed.

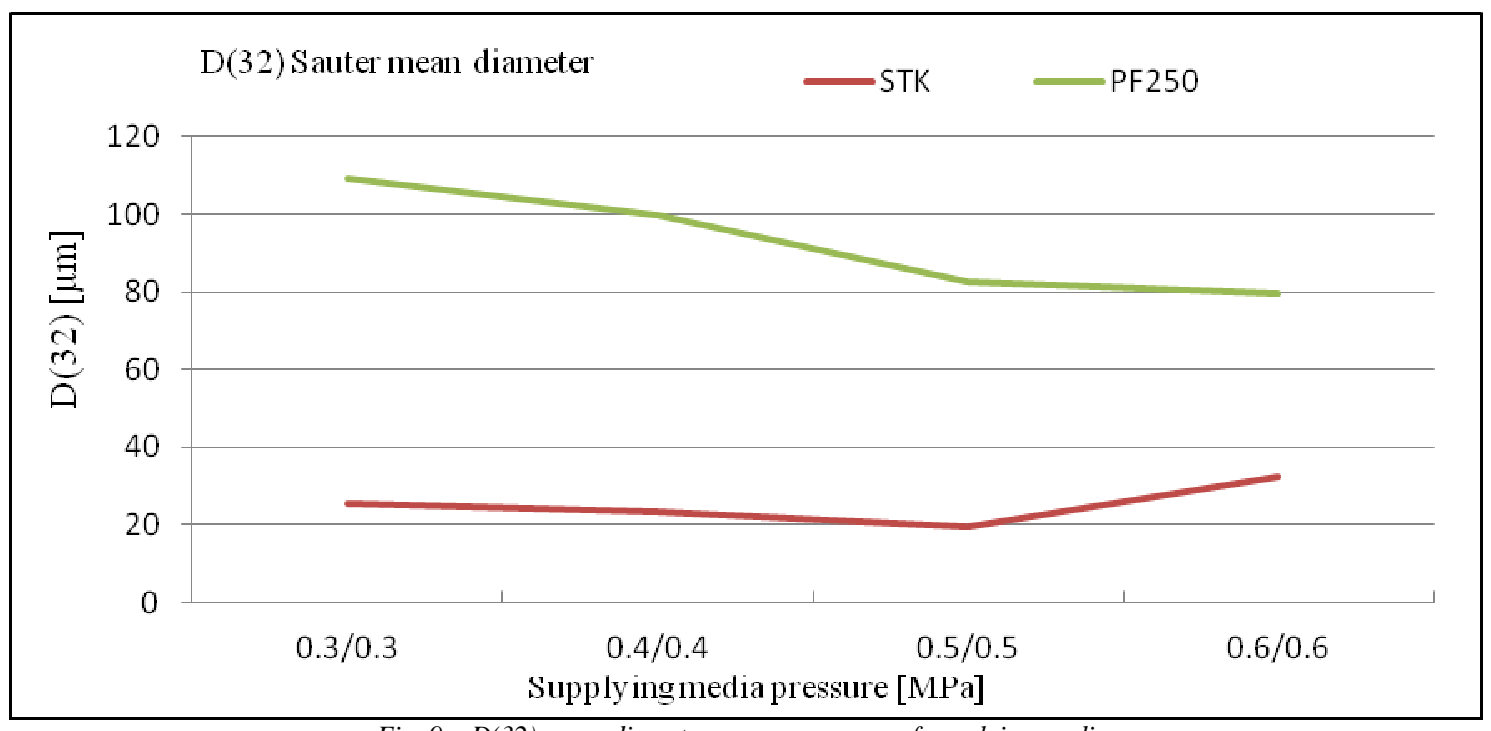

Fig. 9. D(32) mean diameter versus pressure of supplying media

For the analysis of the generated absorption surface area, the diagram of changes in the absorption surface area PA/T versus the combination of supplying media pressure for PF250 nozzle is given in Fig. 9. The best results regarding the surface area, which can be produced within 1 minute are obtained for the combination of air pressure 0.5 $\mathrm{MPa}$ and water pressure $0.3 \mathrm{MPa}$ as well as for air pressure $0.7 \mathrm{MPa}$ and water pressure $0.4 \mathrm{MPa}$. 


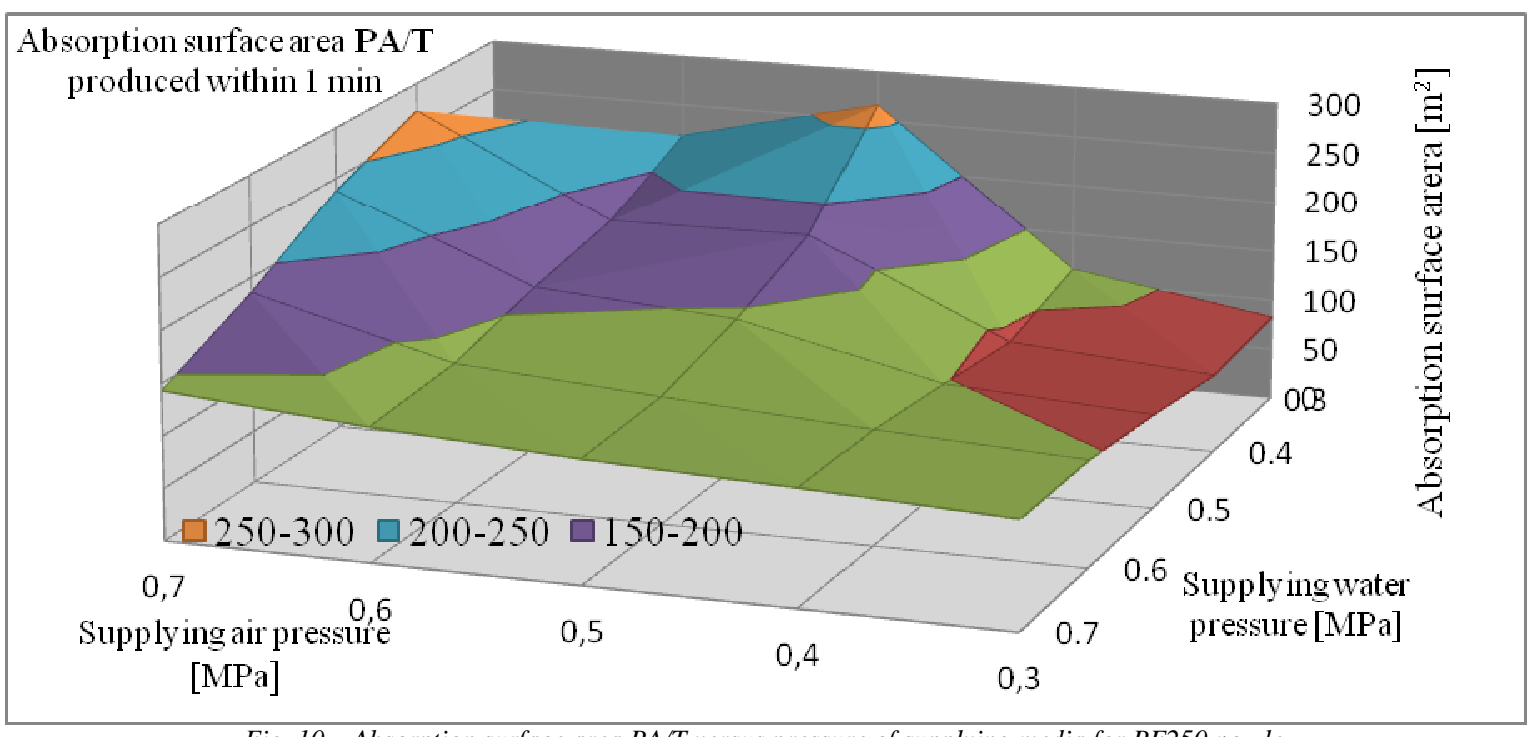

Fig. 10. Absorption surface area PA/T versus pressure of supplying media for PF250 nozzle

Comparison of absorption surface area generated within $1 \mathrm{~min}$ by both nozzles is given in Fig. 11. It can be noticed that PF250 nozzle produced an absorption surface area by about 2-2.5 times greater than STK nozzle.

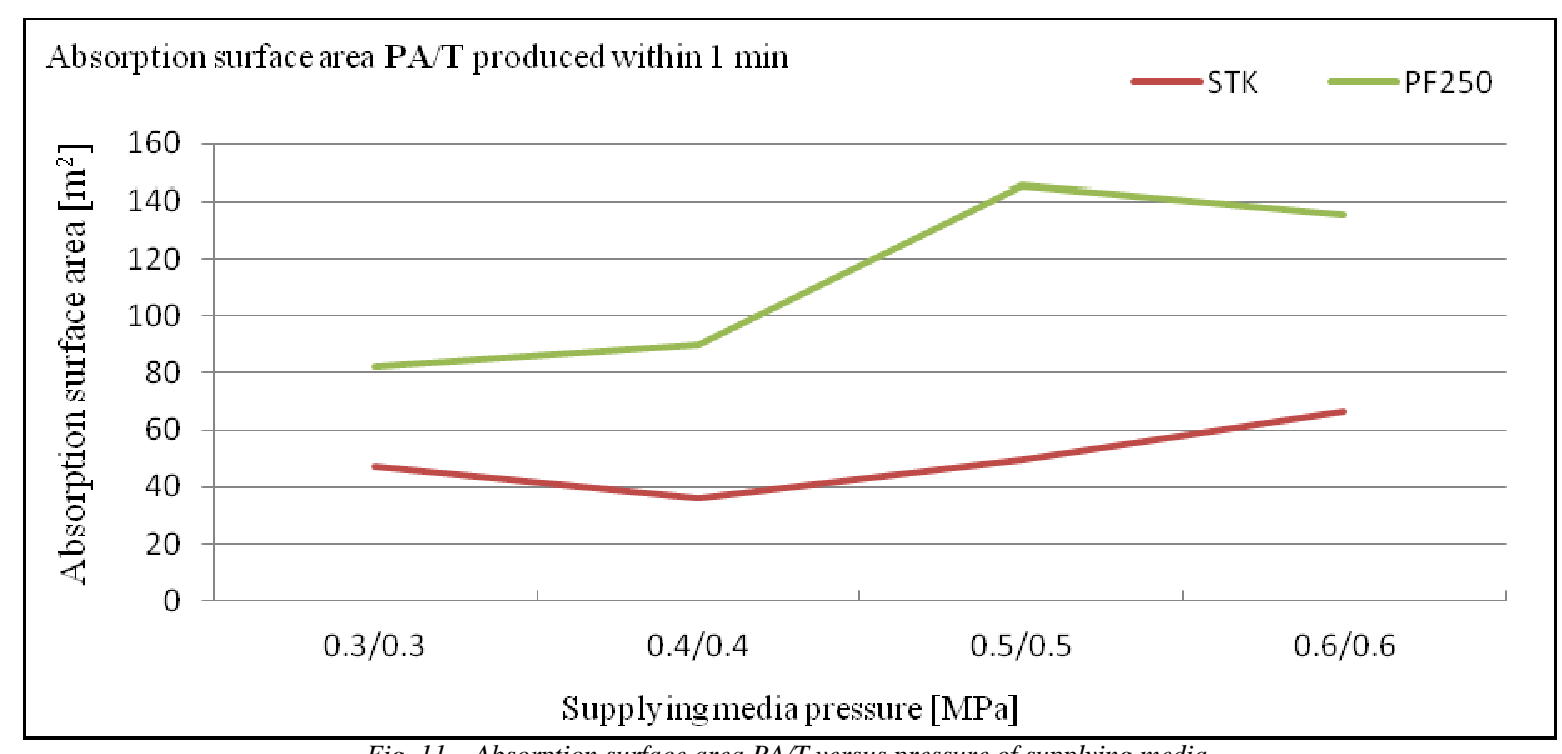

Fig. 11. Absorption surface area PA/T versus pressure of supplying media

In Fig. 12, absorption surface area PA/W changes versus the combination of supplying media pressures for PF250 nozzle is presented. Comparing absorption surface areas produced from $1 \mathrm{dm}^{3}$ of water, an increase of $\mathrm{PA} / \mathrm{W}$ with a decrease in water pressure and increase of compressed air pressure can be observed. 


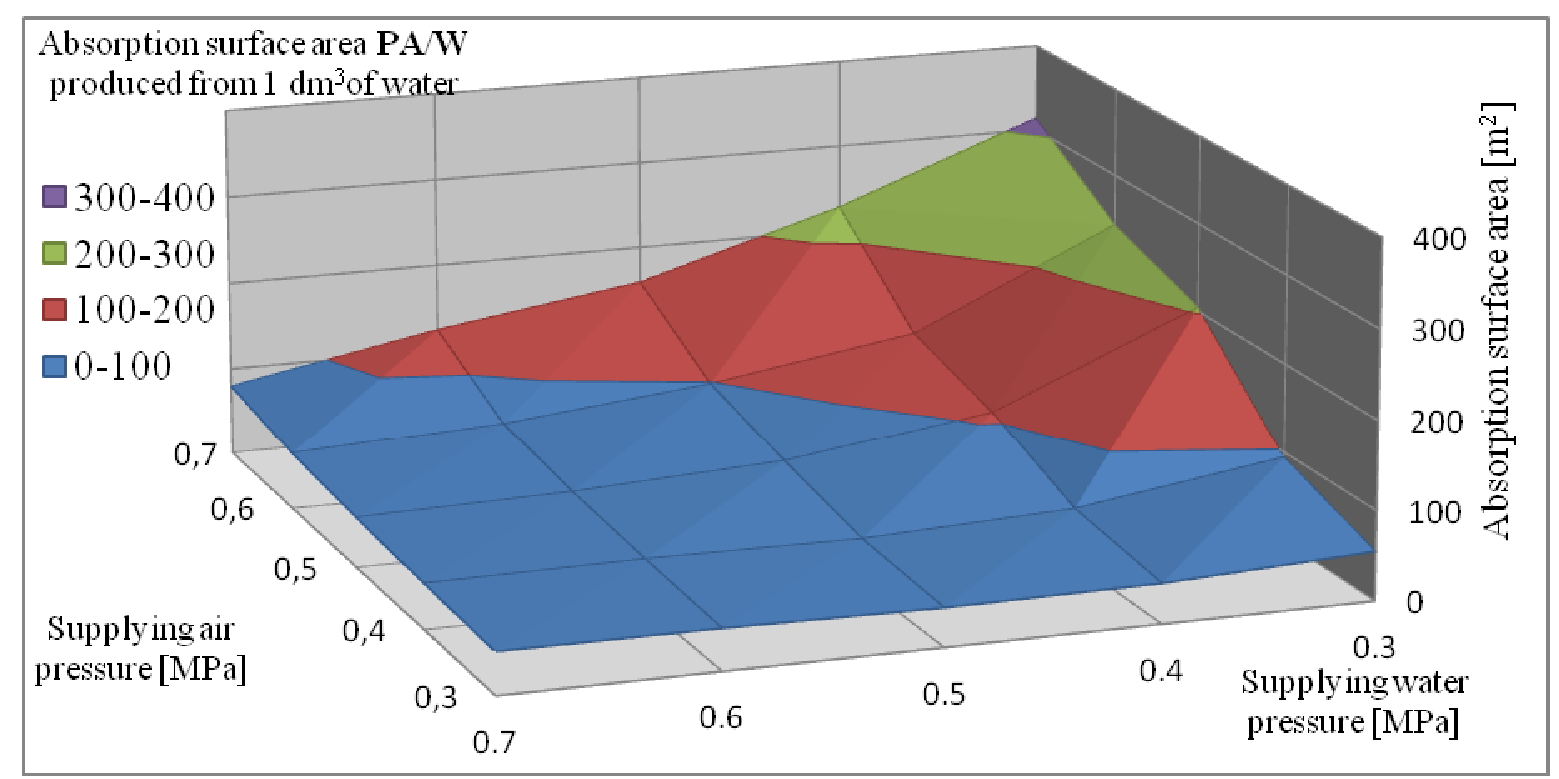

Fig. 12. Absorption surface area PA/T versus pressures of supplying media for PF250 nozzle

Comparison of absorption surface area produced from $1 \mathrm{dm}^{3}$ of water for both nozzles is presented in Fig. 13. STK nozzle produced 3 times greater surface area than PF250 nozzle.

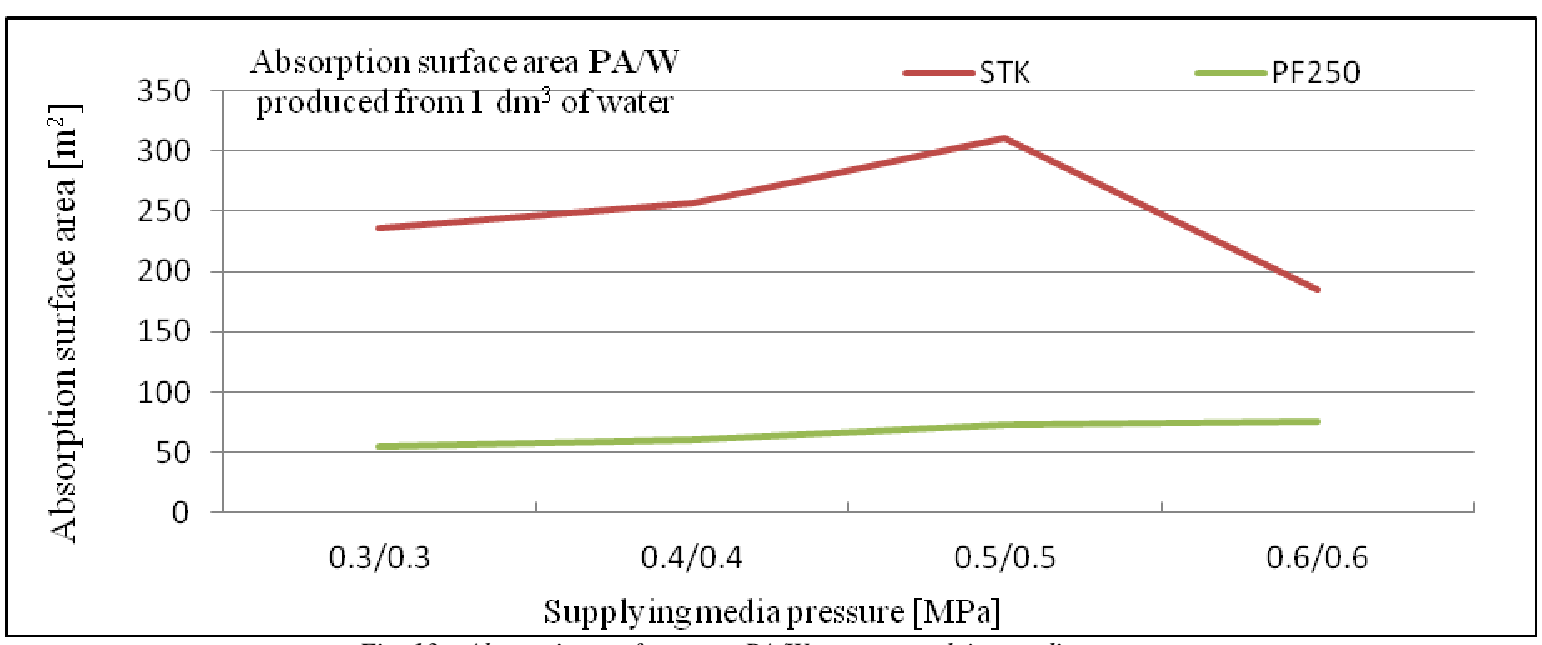

Fig. 13. Absorption surface area PA/W versus supplying media pressure

In Fig. 14 a diagram of changes in absorption surface area PA/P versus supplying media pressure for both nozzles is given. For PF250 nozzle, due to lack of all the data, the diagram is presented only for supply pressures 0.5 and $0.6 \mathrm{MPa}$.

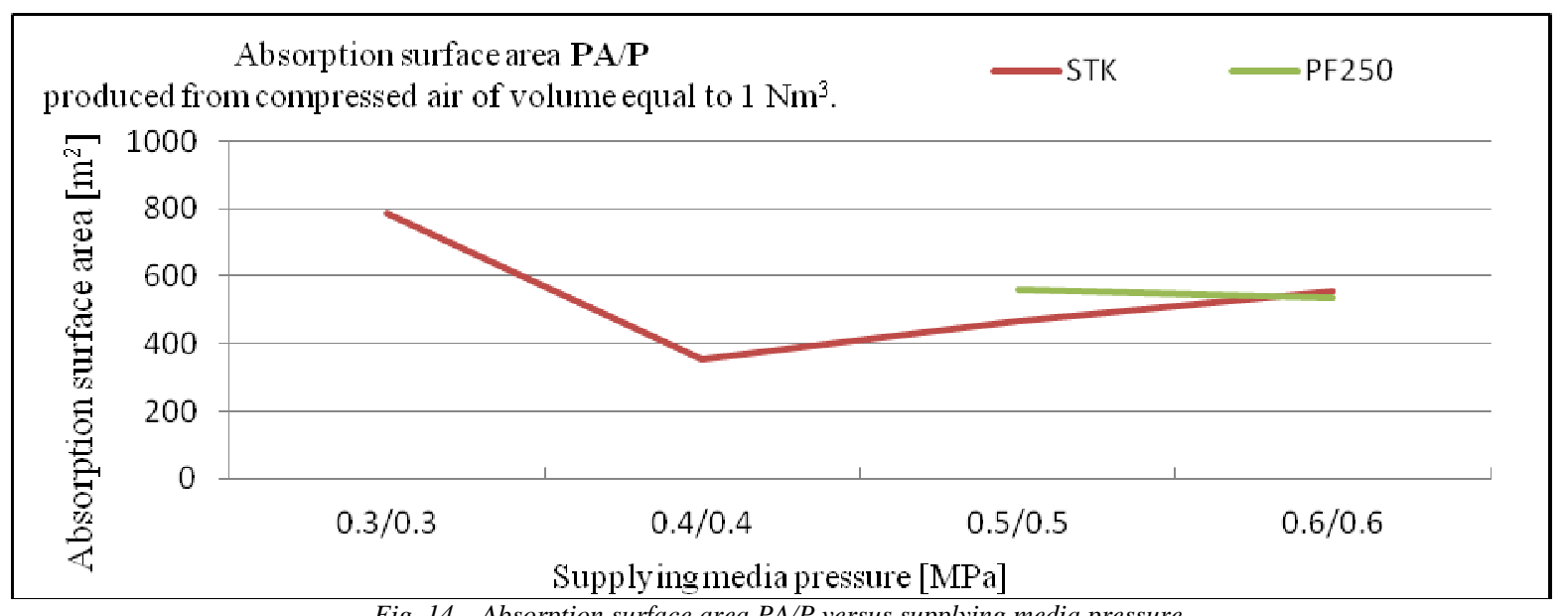

Fig. 14. Absorption surface area PA/P versus supplying media pressure 


\section{Conclusions}

Research projects, realized at KOMAG and focused on development and implementation of the systems for airborne dust control, require correct selection of nozzle type and its diameter. Depending on the place characteristics as well as parameters of available supplying media, the spraying systems should be equipped with the spraying nozzles, adapted as much as possible to the operational conditions. Bearing in mind that increase of dust control efficiency is equiproportional to a reduction of the drop mean diameter in the spraying water stream, type of nozzle should be selected in a way enabling to generate the drops of diameters as small as possible. At the same time, other assumed operational parameters such as range or media flowrate should be followed. Measurements of stream parameters should be taken in a few points within the effective range of the stream to assess stream homogeneity and repeatability of its parameters.

On the basis of the results from testing the PF250 nozzle at different combinations of supplying media pressures, it can be concluded that:

- Change in the pressure of one medium changes the flowrate of both media.

- The smallest $\mathrm{D}(32)$ mean diameter was obtained for the combination of extreme pressures of water (0.3 MPa) and air (0.7 MPa).

- $\quad$ The biggest absorption surface area of a stream generated within $1 \mathrm{~min}$ is obtained for compressed air pressure higher than water pressure by $0.2-0.3 \mathrm{MPa}$.

Comparison of two spraying nozzles of different design enables to conclude that:

- $\quad$ STK nozzle consumes about 5 times less water.

- $\quad$ (32) Sauter mean diameter for PF250 nozzle was about 4 times bigger than STK nozzle.

- Absorption surface area of a stream generated by PF250 nozzle at the same time was $2.0-2.5$ times bigger than the surface area generated by the STK nozzle.

- Taking into account absorption surface area produced from $1 \mathrm{dm}^{3}$ of water, STK nozzle is 5 times more efficient.

- There are no significant differences in compressed air consumption regarding the absorption surface area within a similar range.

\section{References}

Bałaga, D. (2015) Wpływ parametrów strumienia zraszającego na redukcję zapylenia generowanego przez kombajn ścianowy. [Impact of spraying stream parameters on a reduction of dust generated by a longwall shearer]. Doctoral thesis. Gliwice, Poland. (not published).

Bałaga, D. (2019). Assessment of efficiency in reduction of dust concentration in mineral processing plants using the state-of-the-art technical measures. New Trends In Production Engineering, 2(1), 11-19. doi: 10.2478/ntpe-2019-0001

Bałaga, D., \& Jaszczuk, M. (2016) Wpływ parametrów strumienia zraszającego na redukcję zapylenia generowanego przez kombajn ścianowy. [Impact of spraying stream parameters on a reduction of dust generated by a longwall shearer]. Scientific Projects- KOMAG Monographs. KOMAG Institute of Mining Technology No. 47

Bałaga, D., Kalita, M., \& Siegmund, M. (2019). Analysis of fraction distribution of the water drops stream generated by the spraying nozzles of new KOMAG design. Paper presented at the IOP Conference Series: Materials Science and Engineering, , 545(1) doi:10.1088/1757-899X/545/1/012010

Bałaga, D., Kalita, M., Siegmund, M., \& Klimek, Z. (2019). Measurements of dust concentration at workplaces in a hard coal mine processing plants after installation of the NEPTUN spraying system. Paper presented at the IOP Conference Series: Materials Science and Engineering, 545(1) doi:10.1088/1757$899 \mathrm{X} / 545 / 1 / 012005$

Chaussonnet, G., Braun, S., Dauch, T., Keller, M., Sänger, A., Jakobs, T., Koch, R., Kolb, T., \& Bauer, H. -. (2019). Toward the development of a virtual spray test-rig using the smoothed particle hydrodynamics method. Computers and Fluids, 180, 68-81. doi:10.1016/j.compfluid.2019.01.010

Chidambaram E.L., Arunachalam N., \& Vijayaraghavan L. (2015), Analytical Model to Predict Sauter Mean Diameter in Air Assisted Atomizers for MQL in Machining Application. Procedia CIRP,37, pp. 117-121. doi.org/10.1016/j.procir.2015.09.007.

Orzechowski, Z., \& Prywer, J. (1991). Rozpylanie cieczy. [Spraying of liquid.] Warszawa, Poland: Wydawnictwo Naukowo Techniczne, ISBN 83-204-1378-8

Prostański, D. (2012). Dust control with use of air-water spraying system. Archives of Mining Sciences, 57(4), 975-990. doi:10.2478/v10267-012-0065-7 
Prostański, D. (2013). Use of air-and-water spraying systems for improving dust control in mines. Journal of Sustainable Mining, 12(2), 29-34. doi:10.7424/jsm130204

Prostański, D. (2015). Experimental study of coal dust deposition in mine workings with the use of empirical models. Journal of Sustainable Mining, 14(2), 108-114. doi:10.1016/j.jsm.2015.08.015

Prostański, D. (2017a) Zraszanie powietrzno-wodne jako metoda ograniczenia zagrożenia zapłonem metanu i wybuchem pyłu węglowego oraz redukcji zapylenia powietrza. [Air-and-water spraying as a method of reducing hazards of methane ignition and coal dust explosion and a reduction of dust inthe air]. Scientific Projects- KOMAG Monographs. KOMAG Institute of Mining Technology No. 51. ISBN 978-83-6559307-8.

Prostański, D. (2017b). Empirical models of zones protecting against coal dust explosion. Archives of Mining Sciences, 62(3), 611-619. doi:10.1515/amsc-2017-0044

Prostański, D. (2018). Development of research work in the air-water spraying area for reduction of methane and coal dust explosion hazard as well as for dust control in the Polish mining industry. Paper presented at the IOP Conference Series: Materials Science and Engineering, 427(1) doi:10.1088/1757$899 X / 427 / 1 / 012026$

Prostański, D., \& Vargová, M. (2018). Installation optimization of air-and-water sprinklers at belt conveyor transfer points in the aspect of ventilation air dust reduction efficiency. Acta Montanistica Slovaca, 23(4), 422-432.

Semião, V., Andrade, P. \& Graça Carvalho M., (1996). Spray characterization: Numerical prediction of Sauter mean diameter and droplet size distribution. Fuel, 75, pp. 1707-1714 doi.org/10.1016/S00162361(96)00163-9.

Siegmund, M. (2016) Młody naukowiec. Wirtualne prototypowanie konstrukcji dysz zraszających wykorzystujące technologię druku 3D. [Young Scientist. Virtual prototyping of spraying nozzles using 3D print technology]. Report on the work realization. Gliwice, Poland. (not published).

Wang, P., Tan, X., Zhang, L., Li, Y. \& Liu, R., (2019). Influence of particle diameter on the wettability of coal dust and the dust suppression efficiency via spraying. Process Safety and Environmental Protection, 132, pp. 189-199. doi.org/10.1016/j.psep.2019.09.031 